\title{
Events and Books in the Spbere of the Study of Legal and Constitutional History in Hungary in 2019
}

Keywords: scholarly events, Hungary, legal and constitutional history, academic degrees, conferences Słowa kluczowe: wydarzenia naukowe, Węgry, historia państwa i prawa, stopnie i tytuły naukowe, konferencje

\section{Academic Degrees}

Two doctorates were earned in legal history in Hungary in 2019. One went to Lilla Anna Árkosy from the Department of Roman Law of the University of Szeged Faculty of Law. Dr. Árkosy's research topic ${ }^{1}$ is related to trademark law. The title of her doctoral thesis is “Az árujelzöktöl a védjegyig”. Her supervisor was Professor Éva Jakab. ${ }^{2}$ The public submission of her thesis took place at the Szeged branch of the Hungarian Academy of Sciences on 23 September 2019.

The second went to Márton Kálnoki-Gyöngyössy from the Doctoral School of Public Administration Sciences of the National University of Public Service for his research on legal history. Dr. Márton's research topic was the legislative procedures related to Hungarian museums. The title of his doctoral thesis is A magyar múzeumügy a jogszabályalkotás tükrében (1777-2010) [Hungarian Museums and Legislation (1777-2010)], ${ }^{3}$ The submission of Dr. Márton's doctoral thesis took place at the National University of Public Service on 12 April 2019. His supervisor was Zsuzsanna Peres. ${ }^{4}$

1 Árkosy, "Védjegyjog határok"; Árkosy, "Védjegyjog a játékpiacon".

2 Jakab, "Szerződés és konszenzus"; Jakab, "Ein fideicommissum".

${ }^{3}$ Kálnoki-Gyöngyössy, A magyar múzeumügy.

${ }^{4}$ Peres, "A relational contract". 


\section{Monographs and Books in the Sphere of Hungarian Legal History}

Several books on legal history were presented in Hungary in 2019. On 4 October Fejezetek a Szegedi Törvényszék 150 éves joggyakorlatából, the latest volume of the series of books presenting the history of the Szeged Regional Court, managed by the University of Szeged Faculty of Hungarian Legal History was solemnly presented in the building of the Szeged Regional Court. ${ }^{5}$ The editors of the book were: head of the Department of Hungarian Legal History, Mária Homoki-Nagy ${ }^{6}$, Associate Professor Norbert Varga ${ }^{7}$ and senior lecturer Máté Pétervári. ${ }^{8}$ The volume is the fourth book that endeavours to explore the history of the Szeged Regional Court through judicial practice. ${ }^{9}$ In the present volume, we find several stories related to cases of private law, accounts of loan-sharking, and glimpses into judicial practice related to bankruptcy proceedings.

Tamás Antal, an instructor in the Department of Constitutional and Legal History at the Faculty of Law, had two monographs published in 2019. In one of them, he deals with the history of the jury, while in the other one, he covers the history of the Szeged Court of Appeal. The latter is the fourth and final part of our series of books. ${ }^{10}$ The work presents the history of the court between 1938 and 1950, thus ending with the termination of the regional courts.

In 2019, the book by Professor András Patyi of the National University of Public Service on the history of administrative jurisdiction was published. The purpose of the book is to support the understanding of 21 st-century contemporary administrative jurisdiction, especially that of administrative procedural law, by demonstrating its theoretical and historical background. ${ }^{11}$

The work by Instructor Zoltán Megyeri-Pálffi of the University of Debrecen Faculty of Legal History exploring the history of the Royal Court of the Pest Region was also published. $^{12}$

The work by Barna Mezey, head of the Hungarian State and Legal History Department of the Eötvös Lóránt University Faculty of Law, exploring the history of the Hungarian prison system was presented. ${ }^{13}$

Public notary Gábor Rokolya's book demonstrating the history of nationalized public notaries was published. ${ }^{14}$

${ }^{5}$ Homoki-Nagy, Varga, Pétervári, A Szegedi Törvényszék.

${ }^{6}$ Homoki-Nagy, "Történetek a Szegedi".

7 Varga, "Árdrágító visszaélésekkel".

${ }^{8}$ Máté Pétervári, "Csődeljárások a Szegedi".

${ }^{9}$ Homoki-Nagy, Krusóczki, Pétervári, A Szegedi Törvényszék; Homoki-Nagy, Masa, A Szegedi Törvényszék története.

${ }^{10}$ Antal, Fejezetek a Szegedi; Antal, Az angol.

${ }^{11}$ Patyi, A magyar közigazgatási.

${ }_{12}$ Megyeri-Pálffi, Epizódok a Pestvidéki.

${ }_{13}$ Mezey, Lörincz, A magyar.

${ }^{14}$ Rokolya, Az államositott. 
Háborúk alkotások, életutak. Tanulmányok a 17. század közepének európai történelméröl, a volume of studies edited by Gábor Nagy and Noémi Viskolcz, managed by the Miskolc University Press was published. Legal historian György Képes's study entitled The effects of the peace treaties of 1658 and 1660 on Denmark's constitutional development was also included in the volume. ${ }^{15}$

Finally, among notable works published in 2019 was the monograph by, university professor and head of department (University of Szeged Faculty of Law, Department of Legal History) Prof. Dr. Mária Homoki-Nagy entitled Az általam megkért hiteles tanúk elött a következö végsö rendelésemet tészem... Jobbágy-parasztok végrendeletei Szentes mezövárosban which was presented in the Klebelsberg Library of the University of Szeged, on 11 June. On this occasion, historian (University of Szeged, Faculty of Arts, Department of Modern-day Hungarian History) Dr. László Marjanuczhad moderated a discussion with the author.

\section{Collections of Essays and Conferences}

A conference entitled Az emlékezés erejével... which was a part of the jurisdictional history exhibition and conference tour took place in Györ on 7 February 2019, organised by the National Office for the Judiciary, the Györ Regional Court, and the Szent István University Deák Ferenc Faculty of Law and Political Sciences. The opening lecture of the conference, entitled A polgári peres eljárás kodifikációjának elsö fejezete - Az oktrojált normától a kodifikációig, was presented by Professor Barna Mezey. The principles and system of Article LIV of 1868 on civil procedures were reviewed by Associate Professor Attila Barna, while Attila Menyhárd, dean of the Eötvös Lóránd University Faculty of Law, talked about the role of the judge in jurisdictional issues. ${ }^{16}$

On 12 February 2019 the round of events of the Saint Adrian Millennium Memorial Year of the Hungarian law-enforcement agency started with an academic conference entitled Ezer év hazánk és szakmánk történetében. Following the conference held at the Eötvös Lóránd Faculty of Law, an interactive three-day informative series of programmes started in order to demonstrate the new procedures implemented by the lawenforcement agency to increase their social awareness and acknowledgement.

On 4 April 2019 the Faculty of Political Sciences and Public Administration of the National University of Public Service organized a conference entitled 150 éves az 1869. évi IV. törvénycikk. At this jubilee conference, university professor and head of department Barna Mezey gave a lecture entitled Az 1869. évi IV. törvénycikk hatása a magyar börtönügy profiljára. Associate Professor Kinga Bódiné Beliznai gave an overview of 19th and 20th century judicial payment clearing pursuits in her lecture entitled Adj a birónak aranyat, tied az igazság. A bírók anyagi függetlensége. University tutor Attila

15 Képes, Az 1658. és 1660.

16 Mezey, "A dualista”; Menyhárd, "Közjogi vagy". 
Horvath discussed the question of the jurisprudence of the 1950s in a lecture entitled Amikor nem érvényesült a hatalommegosztás elmélete. ${ }^{17}$

On 6 September, 2019, the Court of Gyula organized a jurisdictional history conference entitled Részletek az itélkezési tevékenység történetéböl, különös tekintettel a Békés megyei vonatkozásokra. After President of the Court Árpád Gyula Bagdi’s opening speech, judge Mária Bagossyné Körtvélyesi conveyed a message of greeting from Tünde Handó, President of the National Office for the Judiciary. University professor Mária Homoki-Nagy (University of Szeged Faculty of Law, Department of Hungarian Legal History) elaborated on the jurisprudence of the Court of Gyula with examples from cases of family law and inheritance law from the 1920s. ${ }^{18}$

Organised by the National Office for the Judiciary and the Hungarian Academy of Justice, on 19-20 September, an international conference, at which Hungarian and foreign legal scholars praised the significance of Article IV of 1869 on exercising judicial power, took place in the course of the Jurisdictional History Week at the Palace of Justice. At the conference, Révész T. Mihály, a member of the research group, talked about the elimination of judicial freedom in the 1945-1950 period, and Prof. Barna Mezey analysed the relations between Article IV of 1869 with the historical constitution. ${ }^{19}$

In 2019 the Szegedi Jogtörténeti Napok conference, which is held every other year, took place for the ninth time, organized by the University of Szeged Department of Legal History and led by Prof. Dr. Mária Homoki-Nagy, between 13 and 15 November, 2019 at the headquarters building of the Szeged Regional Committee. The agenda of the conference was broadened by the dedicated session that, commemorating the 135th anniversary of the introduction of the first Hungarian copyright law, dealt with the issues of copyrights, and was carried out on the initiative and with the support of the National Intellectual Property Office. At the conference, researchers dealing with legal history presented their latest research findings. ${ }^{20}$

17 Mezey, “Az európai”; Beliznai, “A bírák”, Horváth, “A bírósági”.

${ }^{18}$ Homoki-Nagy, "A magyar"; Homoki-Nagy, "A három".

${ }^{19}$ Gosztonyi, Révész, "Laudatio".

${ }^{20}$ László, "Caducitas és devolutio", László, “Az Árpád-kori”; Biró. "Foundations of the Uncodified”; Biró. “The legal institution”. Rigó. “The Methods”; Rigó, "Norms and Legal Practice”; Liktor, “„Közjogi vihar a Széll-csendben, Biczó, "Benedikt Carpzov"; Bathó, "A főrendiház közjogi”; Nagy, "Az erdélyi református", Szépvölgyi, "A fogyasztói jogviták"; Szépvölgyi. "A szigorított őrizet”; Drócsa, "Határ a királysértés", Szivós. "The Eventualmaxime"; Szivós. "Questions about the Principle", Szabó, "Nagyszebentől Bécsig"; Legeza. "Development of the Hungarian"; Völgyesi, "Church Archival", Nagy, A jogi kultúrtörténet; Béli, "Időmúlás”; Béli, Benedek Ferenc; Herger, "Az igazságosság”; Korsósné Delacasse, "A calumnia”; Papp, "A rendi dualizmustól”; Lehotay. "Büntetőjogi joggyakorlat”; Szabó, "Az 1919-es Erzberger-féle”, Bognár, Farkas, Györkő, Nagy, Varga. "A családról”; Koncz, "The development”; Képessy, “Az út a kiegyezéshez"; Balogh, "A városi bíráskodás"; Balogh, "How to Make"; Varga, "The Jurisdiction”; Frenkel, Varga (ed.). New Studies in History and LawVarga, "Regulation and Practice"; Varga, "A föispán"; Varga "Az I. világháború"; Beke-Martos, "Strukturwandel und Privatrecht"; Frey, "Strafe ohne Schuld"; Mezey, Die Auswirkungen politisch-sozialer. 


\section{Appointments and Awards}

On 23 August 2019 Dr. Szabolcs Szuromi, Rector of Pázmány Péter Catholic University appointed legal historian Professor Dr. István Szabó dean for another three year term.

The management of the Eötvös Lóránd University Faculty of Law gave the Lippay Award of 2019 to professor of legal history and head of department Dr. Barna Mezey in acknowledgement of his university management work over the course of several decades, his efforts taken in favour of the development of the Faculty of Law, and his impressive activity in establishing a new school of thought in the field of the Hungarian state and legal history.

Based on the decision of the Board of Trustees of the Szegedért Alapítvány [For Szeged Foundation], the major award of the Foundation in 2019 was awarded to legal historian and university professor, Dr. Mária Homoki-Nagy. The presentation of the award, which acknowledged the award winner's work as an instructor, researcher, and supervisor, took place on 12 March 2019, in the National Theatre of Szeged.

Finally, on 31 October 2019, the award ceremony of the Pro Scientia, Pro Arte and Junior Pro Scientia Gold Medals took place at the Hungarian Academy of Sciences. Altogether four medals were awarded in 2019 in the fields of political sciences and law. Two of the four medals were awarded to young researchers researching legal history. In 2019, Enikő Szépvölgyi, doctoral candidate of the Széchenyi István University Doctoral School of Law and Political Sciences (supervisor: Professor Barna Mezey) was awarded the Pro Scientia Gold Medal. Enikö's research topic is connected with the development of issues of poverty in Hungary. Furthermore, Bence Krusóczki, doctoral candidate of the University of Szeged Doctoral School of Law and Political Sciences was awarded a Pro Scientia Gold Medal (supervisors: Prof. Mária Homoki-Nagy and Norbert Varga). Bence's research topic is in connection with the jurisprudence of the first competition law in Hungary.

\section{Bibliography}

\section{Monographs}

Antal, Tamás. Fejezetek a Szegedi Ítélötábla történetéből IV. Szeged-Budapest: Szegedi Ítélőtábla, Országos Bírósági Hivatal, 2019.

Antal, Tamás. Az angol esküdtszék története, Szeged: Iurisperitus Kiadó, 2019.

Árkosy, Lilla Anna. "Védjegyjog határok nélkül. Rövid kitekintés egyéb országok védjegyjogi kodifikációjára." In Jog határok nélkül, ed. by Fejes, Zsuzsanna, 34-39, Szeged: Szegedi Tudományegyetem Állam, 2018.

Árkosy, Lilla Anna. "Védjegyjog a játékpiacon: Hatályos védjegyjogi szabályozásunk alapjai egy jogeset tükrében." In A szellemi tulajdonvédelem és a szabadkereskedelem aktuális kérdései, ed. by Görög, Márta; Mezei, Péter (eds.). Szeged: Iurisperitus Bt., 2018. 
Barna, Attila. “A dualista jogállam polgári perjogának kialakulása: Az 1868. évi LIV. törvénycikk a polgári törvénykezési rendtartás tárgyában”. „Az emlékezés erejével...” - Bíróságtörténeti kiállitás- és konferencia-körút 2018-2019, 2019.

Balázs, László. "Caducitas és devolutio az Árpád-kori királyi jogban”. In Pro Scientia Aranyérmesek XIV. Konferenciája, ed. by Auer, Ádám; Nagy, Noémi; Tóbi, István . Budapest: Pro Scientia Aranyérmesek Társasága, 2019.

Balázs, László. “Az Árpád-kori királyi jog és az államszervezeti funkciók összefüggései rendszerelméleti keretben.” In Tavaszi Szél Konferencia 2019: Nemzetközi Multidiszciplináris Konferencia: Absztraktkötet, ed. by Németh, Katalin, Budapest: Doktoranduszok Országos Szövetsége, 2019.

Balogh, Judit. “A városi bíráskodás”. In Rubicon XXX (2019).

Balogh, Judith. "How to Make a Civil Code: Plans and Drafts of General Rules in 19th-century Hungarian Private Law". Journal on European History of Law. 2020.

Bathó, Gábor. “A förendiház közjogi pozíciója a köztársaság kikiáltása után Wlassics Gyula és Rudnyánszky József álláspontján keresztül, 1918-1920”, ÁLLAM- ÉS JOGTUDOMÁNY 60 (2019).

Beke-Martos, Judit and Husemann, Tim [et al.]. "Strukturwandel und Privatrecht - Jahrbuch Junge Zivilrechtswissenschaft.” Baden-Baden: Nomos Verlag 2019.

Beliznai, Bódiné. “A bírák és bírósági hivatalnokok felelősségéről szóló 1871. évi VIII. tc.” Kuriai Döntések: Bírósági Határozatok: A Kúria Lapja 67 (2019).

Biczó, András. "Benedikt Carpzov Debrecen 18. századi büntető itélkezésére gyakorolt hatásának vizsgálata egy büntetést enyhítő körülmény viszonylatában”. In A hazai és nemzetközi integráció - múltja, jelene és jövője, ed. by Siska, Katalin, 11-28. Debrecen: Debreceni Egyetem Állam- és Jogtudományi Kar, 2018.

Béli, Gábor. "Időmúlás. Az elévülés ismérvei Magyarországon az Anjouk alatt". In Béli, Gábor (ed.). Benedek Ferenc professzor emlékezete: A Zalaegerszegen 2019. június 6. napján megtartott emlékülés elöadásai. Zalaegerszeg: Bíbor Kiadó, Magyar Jogászegylet Zala Megyei Szervezete, 2019.

Biró, Zsófia. "Foundations of the Uncodified Historical Constitution of Hungary." Studia Iuridica 80 (2019).

Biró, Zsófia. "The legal institution of praefectio until 1526, with special attention to the home policy of the Angevines in Hungary: a research work in progress." QUADERNI LUPIENSI DI STORIA E DIRITTO 2019.

Bognár, Szabina [et al.]. “A családról múlt és jelen időben”. Pécs: Pécsi Tudományegyetem 2019.

Drócsa, Izabella. "Határ a királysértés és az izgatás között: A király megsértéséről és a királyság intézményének megtámadásáról szóló 1913. évi XXXIV. törvény anyagi és eljárásjogi elemzése". Iustum Aequum Salutare 2 (2019).

Frey, Dóra. "Strafe ohne Schuld: Konzeptionen der kollektiven Schuld der Ungarndeutschen nach dem zweiten Weltkrieg". In Die Auswirkungen politisch-sozialer umbrüche auf das Strafrecht, ed. by Barna, Mezey, 52-61. Budapest: ELTE ÁJK Magyar Állam- és Jogtörténeti Tanszék, 2017.

Gosztonyi, Gergely and Révész, Mihály. "Laudatio." In Jogtörténeti parerga II: Ünnepi tanulmányok Mezey Barna 65. születésnapja tiszteletére, ed. by Gergely, Gosztonyi and Révész, Mihály, 18-24. Budapest: ELTE Eötvös Kiadó, 2018.

Herger, Csabáné. “Az igazságosság és a jogtalanság határai a magyar magánjogban (1920-1944)”. Jura 25 (2019).

Homoki-Nagy, Maria; Masa, Gabriella. A Szegedi Törvényszék története. Szeged: Szegedi Törvényszék, 2015. 
Homoki-Nagy, Maria and Krusóczki, Bence and Pétervári, Máté. A Szegedi Törvényszék története: Fejezetek a Szegedi Törvényszék magánjogi gyakorlatából. Szeged: Szegedi Törvényszék, 2017.

Homoki-Nagy, Maria and Varga, Norbert and Pétervári, Máté. A Szegedi Törvényszék története, Szeged: Szegedi Törvényszék, 2019.

Homoki-Nagy, Maria. “Történetek a Szegedi Törvényszék működéséről.” In A Szegedi Törvényszék története, ed. by Homoki-Nagy, Maria and Varga, Norbert and Pétervári, Máté (eds.) 5-63. Szeged: Szegedi Törvényszék, 2019.

Homoki-Nagy, Maria. “A magyar magánjog fejlődését befolyásoló jogforrások a neoabszolutizmus idején". In Ünnepi kötet dr. Nagy Ferenc egyetemi tanár 70. születésnapjára, ed by Mária Homoki-Nagy [et al.], 433-443. Szeged: Szegedi Tudományegyetem Állam- és Jogtudományi Kar, 2018.

Homoki-Nagy, Maria. “A három Dóczi végrendelete”. In Kultúra-és tudományköziség a jogi néprajz és a jogi kultúrtörténet metszetében: A VIII. Nemzetközi Hungarológiai Kongresszus (Pécs, 2016. augusztus 22-27.) Jogi néprajz, jogi kultúrtörténet szimpózium elöadásai, ed. by Janka Teodóra, Nagy, 93-110. Szekszárd: PTE Kultúratudományi, Pedagógusképző és Vidékfejlesztési Kar, 2018.

Horváth, Attila. “A bírósági szervezet Magyarországon a szovjet típusú diktatúra korában”. Rubicon 30 (2019).

Jakab, Éva. "Szerződés és konszenzus - a történeti gyökerek". In 70 Studia in Honorem Ferenc Fábián, Boóc, Ádám [et al.], 215-224. Budapest: Károli Gáspár Református Egyetem Államés Jogtudományi Kar, 2019.

Jakab, Éva. "Ein fideicommissum aus der Praxis des Javolenus Priscus: D. 36,1,48(46) (11 epist.)". In Interpretationes iuris antiqui. Dankesgabe für Shigeo Nishimura. Thomas, Finkenauer, ed. by A.J., Boudewijn Sirks. Wiesbaden: Harrassowitz Verlag, 2018.

Kálnoki-Gyöngyössy, Marton. A magyar múzeumügy korai fejezetei: Törvényalkotás és intézményfejlesztés (1777-1918). Budapest: Történeti Muzeológiai Szemle, 2019.

Képes, György. “Az 1658. és 1660. évi békék hatása Dánia alkotmányfejlődésére”. In Háborúk, alkotások, életutak: Tanulmányok a 17. század közepének európai történelméröl. Nagy, Gábor and Viskolcz, Noémi, 43-69. Miskolc: Miskolci Egyetemi Kiadó, 2019.

Képessy, Imre. “Az út a kiegyezéshez”. Forum: Acta Juridica et Politica 9 (2019).

Koncz, Ibolya. "The development of water rights administration in Hungary (A vízügyi igazgatás kialakulása Magyarországon)”. Journal of Agricultural and Environmental Law 14 (2019).

Korsósné Delacasse, Krisztina. “A calumnia mint perbeli csalárd magatartás a Hármaskönyv alapjá". In Benedek Ferenc professzor emlékezete: A Zalaegerszegen 2019. június 6. napján megtartott emlékülés elöadásai, Zalaegerszeg: Gábor, Béli, (ed.), 91-99. Bíbor Kiadó, Magyar Jogászegylet Zala Megyei Szervezete, 2019.

Legeza, Dénes. "Development of the Hungarian 'Work Made for Hire' Provisions". In New Studies in History and Law. Varga, Norbert and Frenkel, David.47-64. Athens: Athens Institute for Education and Research, 2019.

Liktor, Attila. “„Közjogi vihar a Széll-csendben”: Az 1900. évi XXIV. törvénycikk margójára”. Iustum Aequum Salutare 15 (2019).

Megyeri-Pálffi, Zoltán. Epizódok a Pestvidéki Királyi Törvényszék történetéből 1872-1944. Budapest: Budapest Környéki Törvényszék, 2019.

Menyhárd, Attila. “Közjogi vagy magánjogi állam?”. In 350 éves az Eötvös Loránd Tudományegyetem Állam- és Jogtudományi Kara 2. kötet: A jubileumi év konferenciasorozatának tanulmányai, Menyhárd, Attila and Varga, István, 879-890. Budapest: ELTE Eötvös Kiadó, 2018 .

Mezey, Barna and Lörincz, József. A magyar börtönügy története. Budapest: Dialóg Campus, 2019. 
Mezey, Barna. “Az európai börtönügyi tudományosság 19. század kezdetén”. In Kriminológia és kriminálpolitika a jogállam szolgálatában: Tanulmányok Lévay Miklós tiszteletére, ed. by Bárd, Petra and Borbíró, Andrea and Gönczöl, Katalin, Budapest: ELTE Eötvös Kiadó, 2019.

Nagy, Péter. “Az erdélyi református házassági jog forrásai a házassági törvényszékek fennállása idején (1868-1895)". In Az önképtöl és tudásreprezentációtól a hatalommegosztásig - tanulmányok a bölcsészettudomány, a hittudomány és a jogtudomány területeiről, ed. by Furkó, Bálint Péter, 227-248. Budapest: Károli Gáspár Református Egyetem és L’Harmattan Kiadó, 2019.

Papp, László. “A rendi dualizmustól a dualizmus rendjéig: A törvényhatósági rendszer”. Rubicon 29 (2018).

Veronika, Lehotay. "Büntetőjogi joggyakorlat a Miskolci Királyi Törvényszéken 1944-ben.”. Díké: A Márkus Dezsö Összehasonlító Jogtörténrti Kutatócsoport Folyóirata, 2020.

Patyi, András. A magyar közigazgatási bíráskodás elmélete és története. Budapest: Ludovika Egyetemi Kiadó, 2019.

Peres, Zsuzsanna. “A relational contract elmélet és a házassági szerződések.” In Ünnepi kötet a 65 éves Kiss György tiszteletére - Liber Amicorum in honorem Georgii Kiss aetatis suae LXV.

Pétervári, Máté. "Csődeljárások a Szegedi Királyi Törvényszék gyakorlatában”. In A Szegedi Törvényszék története, ed. by Homoki-Nagy, Maria [et al.], 64-109. Szeged: Szegedi Törvényszék, 2019.

Rigó, Balazs. "The Methods for the Legitimacy of the Succession of James II in Aphra Behn's Poem for Coronation". In History of law and other humanities: views of the legal world across the time, Virginia, Amorosi; Valerio Massimo, Minale, 315-327. Madrid: Universidad Carlos III de Madrid, 2019.

Rigó, Balazs. "Norms and Legal Practice of Patriarchalism according to James II's Advices to His Son (1692)". Studia Iuridica 80 (2019).

Rokolya, Gábor. Az államositott közjegyzöség története, Szeged: Iurisperitus Kiadó, 2019.

Szabó, Béla. "Nagyszebentől Bécsig - Professzor sors a dualizmus korában: Leopold Pfaff, magánjogász". Forum: Acta Juridica et Politica 1 (2019).

Szabó, Istvan. “Az 1919-es Erzberger-féle német adóreform: Gondolatok egy szövetségi állam pénzügyi rendszeréröl”. In Magistra et Fautrix - Halustyik Anna emlékére, ed. by Zsolt, Halász, 375-389. Budapest: Pázmány Press, 2019.

Szépvölgyi, Enikö. “A fogyasztói jogviták hatékony rendezésének jelene és jövője”. Jog Allam Politika: Jog- Es Politika Tudomanyi Folyóirat 2019.

Szépvölgyi, Enikő. "A szigorított őrizet, avagy egy fejezet a határozatlan tartamú intézkedések köréből a XX. századi Magyarországon”. Magyar Bünüldözö 9 (2018).

Szivós, Kristóf. "The Eventualmaxime in the Hungarian Civil Procedure - A Historical Perspective". In New Studies in History and Law, ed. by Frenkel, David and Varga, Norbert, 79-89. Athens: Athens Institute for Education and Research, 2019.

Szivós, Kristóf. "Questions about the Principle of Concentration of Proceedings". Studii Si Cercetari Juridice Europene/European Legal Studies and Research 11 (2019).

Varga, Norbert. “Árdrágító visszaélésekkel kapcsolatos jogesetek a Szegedi Királyi Törvényszék gyakorlatából.” In A Szegedi Törvényszék története, Homoki-Nagy, Maria, and Varga, Norbert, and Pétervári, Máté, 110-158 Szeged: Szegedi Törvényszék.

Varga, Norbert. “A főispán és a városi közigazgatás reformja a polgári korban”. Pro publico bono: Magyar Közigazgatás; A Nemzeti Közigazgatás - Tudományi Szamkai Folyóirata 1 (2018).

Varga, Norbert. "The Jurisdiction in the Hungarian Cartel Law: Historical Background". In New Studies in History and Law, ed. by Frenkel, David and Varga, Norbert, 29-47. Athens: Athens Institute for Education and Research, 2019.

Varga, Norbert. "Regulation and Practice of Hungarian Cartel Law in the 20th Century". Athens Journal of Law 5 (2019). 
Norbert, Varga. “Az I. világháború hatása a kartelljog kodifikációjára”. Forum: Acta Juridica et Politica 9 (2019).

Völgyesi, Levente. "Church Archival Collections as Sources of Legal Ethnography". In A jogi kultúrtörténet és a jogi néprajz új forrásai I-II: Jogi kultúrtörténeti és jogi néprajzi interdiszciplináris nemzetközi konferencia, ed. by Nagy, Janka Teodóra, 401-402. Szekszárd: PTE Kultúratudományi, Pedagógusképző és Vidékfejlesztési Kar, 2018. 